\title{
Exotics in the Wetlands: West Indian Marsh Grass ${ }^{1}$
}

Rodrigo Diaz, William A. Overholt, James P. Cuda²

Wetlands (including swamps, bogs, marshes, mires, and lagoons) are important ecosystems that are found on every continent except Antarctica. They can be defined as areas that are inundated or saturated by surface or ground water at a frequency and duration sufficient to support a prevalence of vegetation typically adapted for life in saturated soils (DEP 2003). Wetlands provide essential ecosystems services, and play an increasingly important role in today's world due to urban and agricultural pollution, and modification of natural landscapes. Wetlands clean polluted water, protect shorelines, prevent floods, recharge ground water aquifers, and support high biodiversity and complex food chains.

Invasion of exotic species poses a serious threat to Florida's sensitive ecosystems. International trade, tourism, and agricultural and urban development have increased the probability of establishment of exotic plants. Wunderlin and Hansen (2003) reported 1,316 exotic plants species as naturalized in Florida since European colonization, with 125 species being serious threats to natural areas. Of those, 65 are considered highly invasive because they are disruptive to native plant communities.
Exotic plant species in Florida wetlands spread rapidly due to floods, large waterway systems, and extensive traffic of commercial and recreational boats. Fertilizer and sediment runoff from agricultural lands and waste water from beef and dairy operations may contribute to successful establishment of exotic aquatic plants. West Indian Marsh Grass, Hymenachne amplexicaulis (Rudge) Nees (Poaceae), is one of many species currently invading sensitive wetlands in central and south Florida.

\section{Origin and Distribution}

West Indian Marsh Grass is a native of South America and the West Indies and has spread to most countries of the neo-tropics. The pathway and timing of introduction of this grass into Florida is uncertain; however, the first record was from a ponded pasture in Palm Beach county in 1957 (University of Florida Herbarium). This suggests that the grass could have been intentionally introduced as a forage.

Alternatively, Hill (1996) speculated that migratory birds may have carried $H$. amplexicaulis seeds to Florida from nearby populations in the Caribbean islands. The next record was from a wet pasture in Collier county in 1977 (University of Florida

1. This document is ENY-693, one of a series of the Entomology and Nematology Department, Florida Cooperative Extension Service, Institute of Food and Agricultural Sciences, University of Florida. Publication date: December 2003. Please visit the EDIS website at http://edis.ifas.ufl.edu.

2. Rodrigo Diaz, Ph.D. student, Entomology and Nematology Department, University of Florida, Gainesville; William A. Overholt, assistant professor, Indian River Research and Education Center, University of Florida, Fort Pierce; and James P. Cuda, assistant professor, Entomology and Nematology Department, Cooperative Extension Service, University of Florida, Gainesville, FL.

The Institute of Food and Agricultural Sciences (IFAS) is an Equal Employment Opportunity - Affirmative Action Employer authorized to provide research, educational information and other services only to individuals and institutions that function without regard to race, creed, color, religion, age, disability, sex, sexual orientation, marital status, national origin, political opinions or affiliations. For information on obtaining other extension publications, contact your county Cooperative Extension Service office. Florida Cooperative Extension Service / Institute of Food and Agricultural Sciences / University of Florida / Larry R. Arrington, Interim Dean 
Herbarium). Current records confirm that this grass is present in wetlands and rivers in 13 counties in central and south Florida.

\section{Plant Ecology}

West Indian Marsh Grass invades river banks, marshes and other areas which seasonally flood. It grows from stolons which can be fragmented by flowing water and transported great distances downstream. Therefore, seasonal flooding associated with summer rainfall in Florida is conducive to the spread of this plant. This grass also can be spread by seeds that are produced in large quantities and are highly viable. If the grass invades water storage facilities, additional spread of seeds and stolons can occur via secondary irrigation canals.

Observations of the dynamics of West Indian Marsh Grass in Myakka River State Park suggest that during December to February, when temperatures are low and the marshes are relatively dry, plants die back and large amounts of biomass accumulate on soil surface. Once the temperatures start to increase in the spring, a variety of native wetland plants coexist in marshes with emergent regrowth and seedlings of West Indian Marsh Grass. Later, as temperatures and water levels rise in the summer, the marshes become a virtual monoculture of West Indian Marsh Grass.

A characteristic of West Indian Marsh Grass that promotes invasion of wetlands is its adaptation to flooding. Kibbler and Bahnisch (1999) found that it rapidly increases stem length, number of nodes per stem, and internodal length as water levels increase.

\section{Impact on Wetlands}

Wetlands are thought to be more susceptible to plant invasion than other ecosystems because of greater water and nutrient availability, and low plant diversity (Fox and Fox, 1986). West Indian Marsh Grass threatens wetland biodiversity, through simplification of both species and habitat diversity. Large stands of West Indian Marsh Grass reduce resources available for feeding, breeding and shelter of native fauna. In a recent study, Houston and Duivenvoorden (2002) found that wetlands invaded with $H$. amplexicaulis had lower plant species richness, greater relative abundance of exotic fish and altered macroinvertebrate community structure.

West Indian Marsh Grass has the potential to block irrigation channels and other waterways. It spreads rapidly from dense mats above or below the water, reducing light levels reaching submerged aquatics and the benthic (bottom of a body of water) environment. This further contributes to reduced diversity and also increases the amount of decaying organic matter, which in turn, depletes oxygen levels. Thus far, the distribution of West Indian Marsh Grass in Florida appears to be restricted to relatively small aquatic environments, but larger wetland systems such as the Everglades National Park, Big Cypress Swamp, and the St. Johns River may be susceptible to invasion, which would have profound ecological and economic consequences.

\section{Plant Identification}

West Indian Marsh Grass can form large stands (Figure 1) and is well adapted to flooding conditions. The plant is a stoloniferous (bears or developes runners), perennial grass, $1-2.5 \mathrm{~m}$ in height. Leaf blades are $10-50 \mathrm{~cm}$ long and up to $4 \mathrm{~cm}$ wide, mostly lanceolate (tapering to a point) and cordate (heart shaped) at the base (Figure 2). The glabrous (smooth or bald) stems are erect or ascending from a prostrate (spread out) base and are filled with white pith (aerenchyma) (Figure 3). The panicles (Figure 4) are narrow, spike-like, cylindrical, $20-40 \mathrm{~cm}$ long (Bodgan 1977) and flowering begins in July in central Florida.

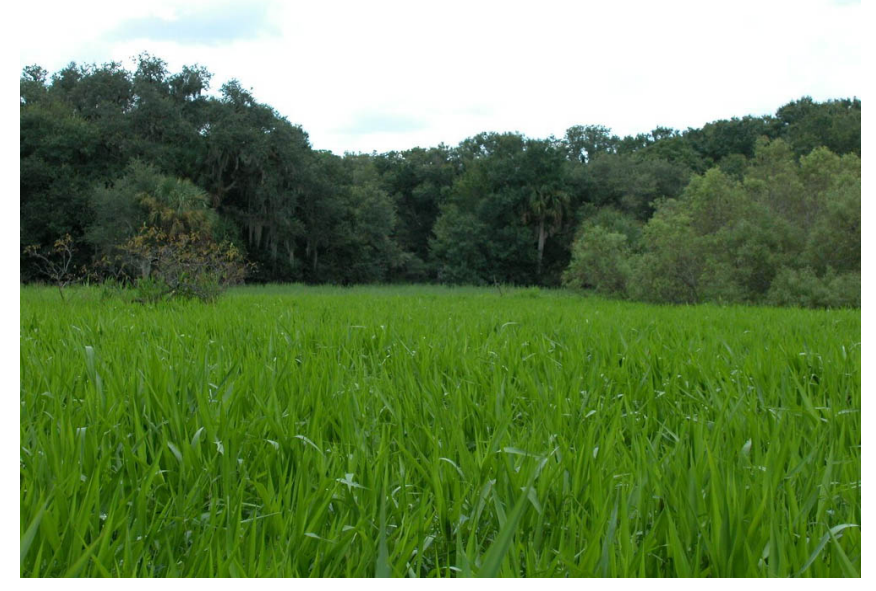

Figure 1. West Indian Marsh Grass spreads by stolons and forms large stands. Credits: University of Florida 


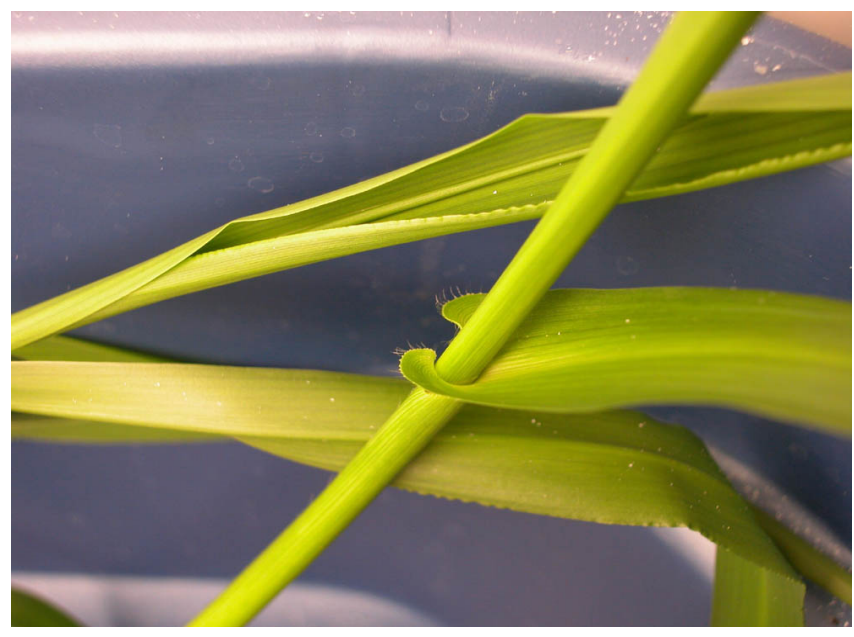

Figure 2. Leaf base showing cordate structure. Credits: University of Florida

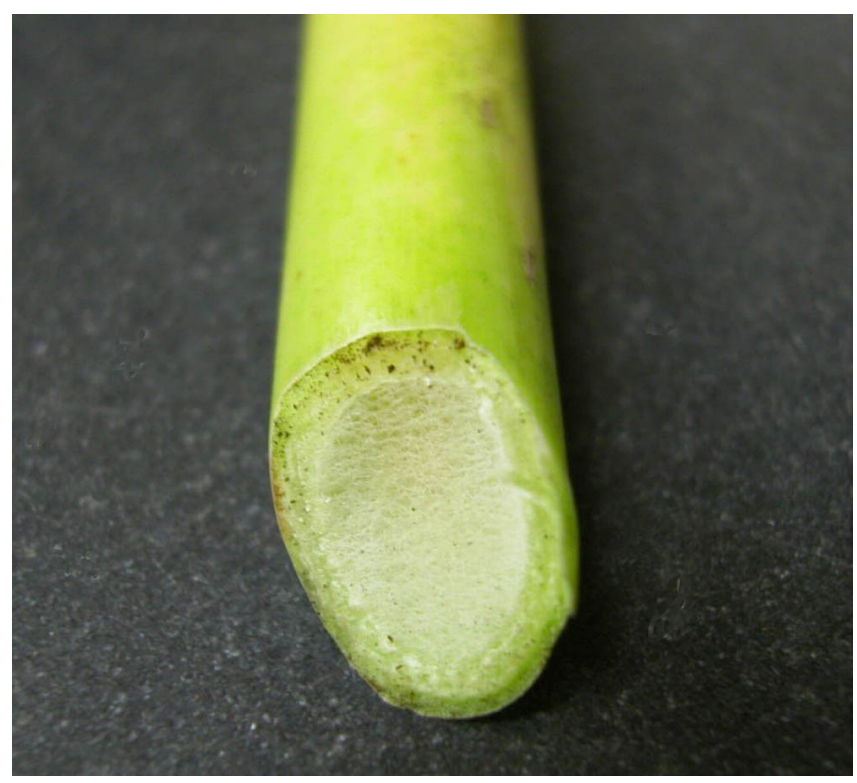

Figure 3. White pith in stem (aerenchyma). Credits: University of Florida

\section{Control Methods}

Herbicide recommendations vary depending on site conditions. In wet areas, glyphosate labeled for aquatic use can be applied at 10.521 per hectare ( 7 $1 / 2$ pints per acre). In dry areas, 0.95 liters (1 qt) imazapyr can be added to the glyphoste. Appropriate surfactants should be used in both cases as indicated on the herbicide labels. Other control methods include manipulation of water levels (drying or drowning the plant), removal with heavy machinery, use of plastic sheets to solarize infested areas, and shading by tall vegetation.

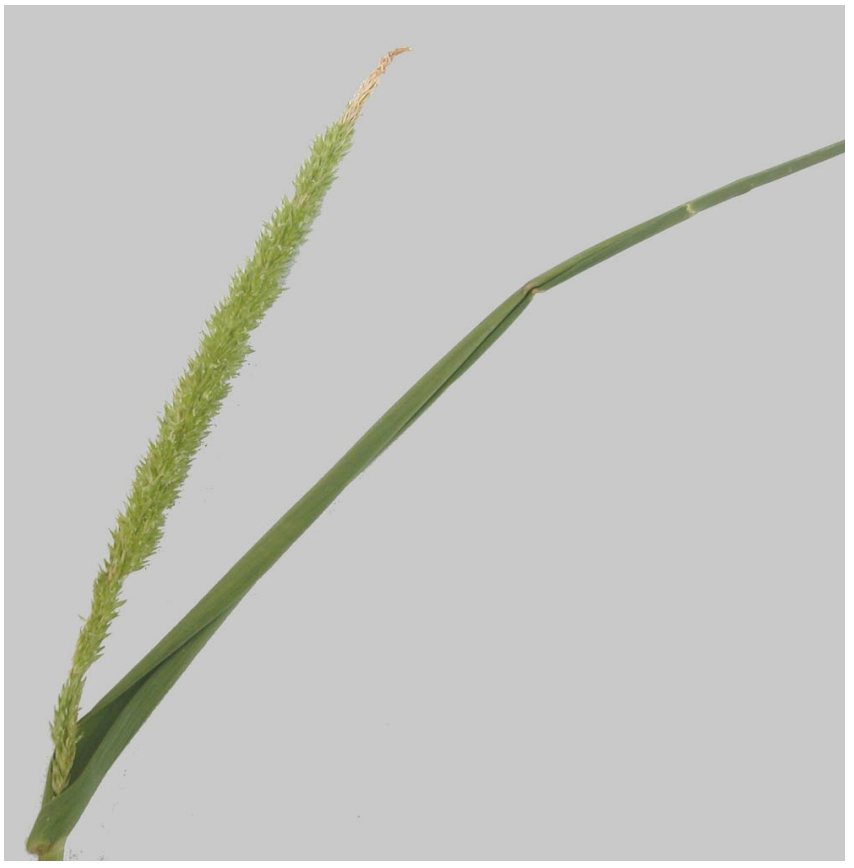

Figure 4. Spike-like panicle $(\mathrm{cs} .30 \mathrm{~cm})$. Credits: University of Florida

\section{How You Can Help}

Residents interested in protecting Florida's aquatic habitats can help by identifying locations where West Indian Marsh Grass occurs. Knowing the current distribution of the grass can improve our management efforts in invaded areas and prevent its spread to non-invaded areas. If you find new stands of West Indian Marsh Grass, please contact the local land manager, or agencies such at the Cooperative Extension Service, the relevant water management district, or the Department of Environmental Protection (Table 1).

\section{Literature Cited}

Bodgan, A. V. 1977. Tropical pasture and fodder plants (Grasses and Legumes). Longman Inc., New York.

DEP. 2003. Delineation of the landward extent of wetlands and surface waters.

http://www.dep.state.fl.us/water/wetlands/docs/ delineation/intro.pdf.

Fox, M. D. and Fox, B. J. 1986. The susceptibility of natural ecosystems to invasion. In: Groves, R. H. and Burdon, J. J. (eds.), pp. 57-66. 
Table 1. Telephone numbers and contact persons to report populations of West Indian Marsh Grass.

\begin{tabular}{|l|l||}
\hline \multicolumn{1}{|c|}{ Institution } & \multicolumn{1}{|c}{ Name/Phone Number } \\
\hline South Florida Water Management District & Mike Bodle, 561-687-6132 \\
\hline Southwest Florida Water Management District & Bryan Nelson, 800-423-1476 x4537 \\
\hline Indian River Research and Education Center & Bill Overholt, 772-468-3922 x143 \\
\hline Department of Environmental Protection & Kathy Burks, 850-245-2809 \\
\hline \hline
\end{tabular}

Ecology of Biological Invasions: An Australian

Perspective, Australian Academy of Science, Canberra.

Hill, K. 1996. Hymenachne amplexicaulis: A Review of the Literature and Summary of Work in Florida. University of Florida Extension. http://www.naples.net/ kuh/hymen.htm.

Houston, W. A. and L. J. Duivenvoorden. 2002. Replacement of littoral native vegetation with the ponded pasture grass Hymenachne amplexicaulis: effects on plant, macroinvertebrate and fish biodiversity in the Fitzroy River, Central Queensland, Australia. Marine and Freshwater Research.

53:1235-1244.

Kibbler, H. and L. M. Bahnisch. 1999. Physiological adaptations of Hymenachne amplexicaulis to flooding. Australian Journal of Experimental Agriculture 39: 429-435.

Wunderlin, R. P., and B. F. Hansen. 2003. Atlas of Florida Vascular Plants (http://www.plantatlas.usf.edu/). [S. M. Landry and K. N. Campbell (application development), Florida Center for Community Design and Research.] Institute for Systematic Botany, University of South Florida, Tampa. 